\title{
An Investigation of Audit Quality in Mauritius
}

\author{
Auhammud Bibi Mushiirah, Seetah Keshav, Pariag Maraye Neeveditah* \\ University of Mauritius, Réduit, Moka, Mauritius \\ Email:*n.pariag@uom.ac.mu
}

How to cite this paper: Mushiirah, A.B., Keshav, S. and Neeveditah, P.M. (2018) An Investigation of Audit Quality in Mauritius. Theoretical Economics Letters, 8, 2773-2787. https://doi.org/10.4236/tel.2018.813174

Received: June 25, 2018

Accepted: September 26, 2018

Published: September 29, 2018

Copyright $\odot 2018$ by authors and Scientific Research Publishing Inc. This work is licensed under the Creative Commons Attribution International License (CC BY 4.0).

http://creativecommons.org/licenses/by/4.0/ (c) (i) Open Access

\begin{abstract}
Objectives: The objective of the study was to investigate the importance of audit quality in Mauritius and the factors affecting audit quality in Mauritius, from the perception of accounting professionals in Mauritius. Methodology: For the purpose of this study, a survey was carried out among accounting professionals in Mauritius. Based on existing literature, the questionnaire was designed and a five point-likert scale was used. The target population was accountants, auditors and stock brokers who were used as a proxy for investors. A stratified random sampling approach was used for the purpose of this study. A sample size of 200 accounting professionals was out of the 200 questionnaires administered, 188 were collected, of which 8 were discarded because they were not properly filled. Statistical analysis techniques for example; Factor Analysis, Descriptive Statistics, Independent Samples T-test and One-Way-ANOVA were used for the purpose of analysis. Findings: Majority of respondents have shown agreement with the importance of audit quality for its multiple beneficial contributions to successful corporate performance, and good governance in general. In addition the impacting factors on audit quality, by Turley and Willekens [1], regarding audit fees, firm size, tenure, reputation, financial statements-restatements, industry expertise, independence, non-audit services, and audit rotation, have been perceived as essential for achieving audit quality in Mauritius. The study reveals that female are more agreeable than male that audit quality enhances firm performance. The study also reveals that female are more agreeable than male that Long auditor tenure leads to high audit quality and that financial restatements of faulty statements negatively impact audit quality. Scope for Future Research: The study has investigated the audit quality from the perspectives of accounting professionals. Further study can include the perception of different users of accounting information such as shareholders, potentials investors, creditors, customers, employees amongst others to have a better evaluation of audit quality in Mauritius.
\end{abstract}




\section{Keywords}

Audit Quality

\section{Introduction}

The role and importance of the audit function in public, parastatal or private-sector entities has increasingly been attracting attention from various quarters, over recent years [2]. As an all-important mechanism in a private-sector company's financial management and controlling system, and viewed specifically in terms of how effectively it serves towards enhancing company performance while inclusively protecting company assets as well as investors', creditors' and other stakeholders' rights and interests, the auditing function has to be significantly credible, trustworthy and reliable [3]. Viewed from the perspective of Mauritius, as a fast developing economy ambitioning to emerge into an economic force in the African region and pledging to gain recognition as offshore/financial centre of substance, it is becoming increasingly crucial to ensure financial statements and audit reporting to the highest standards of quality, in compliance with the International Auditing and Assurance Standards Board (IAASB [4]).

Acknowledging the need for remedying to diverse gaps or deficiencies in the Mauritian financial reporting and auditing functions, the Mauritian Government passed laws for regulating financial service operations. The trend of fraudulent practices, characterized by scandals such as Enron and Parmalat on the international front seems to be gaining ground in Mauritius-if any credibility is to be given to media reports over recent years. Already, serious doubts continue to be expressed publicly about how some Mauritian corporate entities may have been concealing their true financial situation or the huge losses of their related companies, through manipulated financial statements, sometimes in collusion with external auditors. This is where the vital importance of clean and high quality auditing appears to be attracting the attention of publics and various players or stakeholders in the Mauritian business environment.

The pertinent question that crops up is the quality of audit exercised by external auditors when auditing financial statements of companies and giving an opinion of the companies' financial performance and financial position. Users of accounting information rely on audited financial statements to make informed decision regarding allocation of scarce resources. Poor audit quality is likely to mislead users of accounting information and may lead to wrong decision making. It is therefore imperative to gain informed insights into those critical factors that impact audit quality. The objective of the study is to investigate the importance of audit quality and factors by which it is affected from the perspectives of accounting professionals.

Mauritius is a developing economy as well as a small island economy that has 
experienced significant economic success since its independence in 1968. Studies on audit quality are concentrated in developed economies and few studies have conducted in developing economies. In addition such studies are scarce in small island economies. This study contributes to the literature on audit quality in developing economies as well as in small island economies such as Mauritius.

The paper continues as follows. Section 2 consists of the literature review, Section 3 explains the methodology of the study, and Section 4 comprises the findings of the study and the discussion of the results. Section 5 concludes and provides relevant recommendations.

\section{Literature Review}

Francis [5] as well as De Fond and Zhang [6] emphasize the need for auditors to produce a fair and honest view of a firm's financial position through audit opinions based on authentically sound measures and thorough documentation.

\subsection{Importance of Audit Quality}

Hussein and Hanefah [7] and Hosseinniakani et al. [8] hold that contemporary business and service entities are attributing greater and greater importance to audit quality assurance because of the various useful purposes that it serves, in terms of promoting and sustaining stakeholders' and public trust and confidence in financial statements, thus urging auditors or audit firms to produce audit reports of the highest quality [9].

Jin et al. [10] claimed that stakeholders' and, indeed, publics' trust and confidence had been thoroughly eroded following the Enron and WorldCom scams, leading to the collapse of these two giants, at the near end of the last century. Realizing the urgent need for remedying to such loss of trust and confidence, the IAASB pressed for audit professionals' rigorous adherence to audit quality assurance and controlling mechanisms to ensure compliance with truly international standards, as an effective deterrent to fraud and other malpractices [4].

With audit quality contributing as it does to enhancing the reliability of audit reports or financial statements, the need for redoubling efforts in such direction is increasingly being acknowledged as an imperative [1]. The contributions can be measured mainly in terms of highly beneficial influences with respect to a firm's image and reputation, greater assurance and confidence in audited financial statements, and benefits for public interests. It is stated that this significantly contributes to ensuring success in a more sustainable manner.

With regard to firm's reputation, Choi et al. [3] stated that once a firm has built its reputation through consistently ensuring audits of the highest quality, it will stand to gain from enhanced credibility levels. The direct benefit of such added creditworthiness is that decision-makers and investors will be more likely to value the auditor's findings, conclusions or recommendations and more disposed to implement same. Thus, the need for ensuring audit quality to the highest international standards can stimulate domestic as well as foreign direct 
investment (FDI) flows.

It is DeAngelo's [11] view that given that audit firms' findings or recommendations are bound to be challenged at one time or other, particularly in a context characterised by fraud and other financial malpractices (Enron, Parmalat or the Kaupthing Bank or the BAI scam, within our own shores, are but a few eloquent examples), no audit professional should overlook the authentic value of audit quality. In fact, there are so many constituencies ever ready to challenge the soundness of an audit report. Even the minutest error revealed, or a finding disproved, brings water to the mill of contestants, thereby significantly damaging diverse publics' as well as stakeholders' trust and confidence [12].

According to Geiger and Rama [13], any effort to ensure that public interest is protected while the needs of users of audit works are truly met, must be founded on authentically functioning audit quality mechanisms. It is all a matter of responding to healthy standards of accountability required of state or parastatal bodies. When audit reports or findings are free from misrepresentations, distortions, or bias, it is more than likely that thoroughly-documented audit analyses will ensure stakeholders' or public adhesion or approval, leading in turn to enhanced levels of trust, confidence and assurance [14]. These writers claimed that, in the process, audit quality is sure to demonstrate that principles of good governance are truly functioning in the best interest of a country and its people.

It is claimed that today the pressures for ensuring improved assessment of risk are increasing considerably across the world (Epstein and Buhovac, 2006). This trend originates from the necessity to counter the various breaches of established principles which have tended to become rather common these days, thus adversely impacting corporate governance as much as a country's good governance levels.

Studies on audit quality are concentrated in developed economies and few studies have conducted in developing economies. In addition such studies are scarce in small island economies such as Mauritius. There is a gap in the literature of audit quality with regards to developing economies and small island economies. This study attempts to reduce this gap.

\subsection{Factors Affecting Audit Quality}

It is now appropriate to shift attention to those factors that are observed to have an impact on audit quality. These, according to Turley and Willekens [1], include: Audit fees, Audit Firm Size, Audit Tenure, Audit Firm's Reputation, Financial Statement-Restatement, Audit Industry Expertise, Auditors' Independence, Non-Audit Services, and Audit Rotation.

It is claimed by O'Sullivan and Diacon [15] that audit fees tend to be mirrored not only by complexity, audit hours taken, or the risk factor, but also by the kind of specialized service required. Inevitably, then, audit quality to ensure that financial statements are free from misrepresentations, distortions, or bias, is impacted by audit fees [16] [17]. 
Larger firms that offer auditing services adopting more elaborate audit procedures, it is only logical that the quality of audit work is going to be enhanced. Also, as perceived by Kilgore [18], audit firm size is a common surrogate for creating audit quality. Otherwise, as upheld by DeAngelo [11], when firm size is large, concern about not losing client companies means that the firm in question will make sure that audit quality is sustained. This view is also shared by Hussein \& Hanefah [7]. They found that large audit firms find themselves in a situation where due attention must be given to professional competence, high auditor's qualification, and highly selective recruitment of talented as well as knowledgeable supporting staff.

It has been demonstrated by some studies that knowledge ability level between client and audit firm is influenced by audit tenure. According to Crabtree [19], when audit tenure augments it is more likely that the auditors' knowledge about the client will increase and vice-versa. Studies have established that audit firm-client relationship grows stronger when the audit tenure is longer [14]. This condition has also been found to be characterized by more frequent audit reporting failures during the initial period of the long tenure, with the situation improving in the long run, as audit quality is enhanced.

According to Susanty and Gunawan [20], the performance of audit firms and auditors concerned with sustaining their reputation, can also be viewed as a catalyst towards a new direction where individual performance becomes the competence indicator of auditors. No wonder, then, that emerging auditors are ever concerned about the growing importance of achieving competitive advantage through sustaining audit quality efforts, consistently. Looking into the linkages between firm's reputation and quality of audit work, Aronmwan et al. [21] revealed that such relationship is definitely positive, with audit firm's reputation having a welcome impact of on the second variable.

Liu et al. [22] are of the view that frequent financial restatements do mirror audit failure. They found that when faulty financial statements had to be restated, the expertise of the audit firm may be questioned, thus impairing auditor's credibility and creditworthiness, impacting audit quality in turn. Likewise, when investors trust and confidence in a firm's credibility negative are lost, adverse perceptions can develop and lead to negatively affected performance ahead [23]. They found that high quality audit increases as the number of accounting restatements decreases.

Reichelt and Wang [24] stressed how importantly auditing expertise in terms of technical competence raised to higher levels may go hand in hand with technical information expertly handled to effectively and efficiently reveal errors of misstatement in financial reporting. Industry-specific expertise is increasingly being recognized as a strong contributor to audit quality enhancement, with auditors adopting and expressing more conservative opinions in their reports.

Referred to as objective and hence, impartial judicial approaches to ascertain the production of honest and fair opinions on the financial position of entities, with an obligation to meet creditors' and other interested constituencies' demands 
for audited financial statements free from errors and omissions, audit independence is purported to be vitally important for ascertaining audit quality. Gatekeeping public securities in contemporary marketplaces therefore require the emergence of authentic auditing, characterized by a good measure of independent opinions expressed by firms [25].

It is claimed that by providing non-audit services, audit firms compromise on the quality of their auditing standards or opinions, as stressed by Alleyne et al. [26] as well as Francis [27], a couple of years earlier. When non-audit services are offered auditor's impartiality or independence are at risk, thereby causing stakeholders or investors to be suspicious of financial statements and auditing reports [28].

The conclusions of Dopuch et al. [29] imply that the tendency of resorting to voluntary retention of auditors by manager-subjects is more pronounced under Regimes 1 and 2, for multi-periods, with the risk of audit quality and independence being eroded, becoming more likely to happen, as audit tenure stretches to longer periods. Retention also implies that through manager-subjects and auditor-subjects developing deeper relationships, higher investment levels are initiated by managers.

\section{Methodology}

For the purpose of this study a survey was carried out among accounting professionals in Mauritius. Based on existing literature, the questionnaire was designed and a five point-likert scale was used, 1 being strongly disagree (SD), 2 being disagree (D), 3 being neutral (N), 4 being agree (A) and 5 being strongly agree (SA). . Respondents were questioned regarding their level of agreement and disagreement with respect to different statements of the questionnaire. Gender, age, level of experience and qualifications of respondents were also considered. The target population was accountants, auditors and stock brokers who were used as a proxy for investors. A stratified random sampling approach was used for the purpose of this study. The sample size was 200 accounting professionals.

In order to verify the content validity of the questionnaire, a pilot test was carried out among ten accounting professional and some changes were made following the pilot test. Then the revised questionnaire was administered to the 200 respondents. Out of the 200 questionnaires administered, 188 were collected, of which 8 were discarded because they were not properly filled. This implies that finally, only 180 duly-filled valid questionnaires were considered for analysis purposes. SPSS 20.0 was used for analysis purposes. Statistical analysis techniques for example; Factor Analysis, Descriptive Statistics, Independent Samples T-test and One-Way-ANOVA were used for the purpose of analysis. With regards to Exploratory Factor Analysis (EFA), a cut-off point of 0.5 was used for the factor loading as recommended by Hair et al. (2006). Consequently items having factor loading below 0.5 were eliminated. Independent Samples T-test and One-Way-ANOVA was used to investigate differences among variables. In addition to test for dimensionality of scales factor analysis was used and reliability 
test was carried out to test the reliability of dimensions using Cronbach's Alpha Coefficient.

\section{Results and Discussions}

$54 \%$ of the respondents were male and $46 \%$ were female. $6 \%$ of respondents were aged between $18 \%$ and $25 \%, 34 \%$ were in the range 26 - 35, 36\% were between $36 \%$ and $45 \%$ and $24 \%$ were above 46 . More than $52 \%$ of respondents were degree holders and more than $31 \%$ were ACCA qualified.

\subsection{Exploratory Factor Analysis: Importance of Audit Quality}

With the use of the Varimax method, a factor analysis was conducted to check whether different factors rearranged under the similar constructs. In order to assess the strength of the different factors, the Kaiser-Meyer-Olkin (KMO) Measure of Sampling Adequacy and the Barlett's test were carried out before the analysis. KMO was 0.590 which was higher than the required minimum of 0.50 and the significance value for the Barlett's test was 0.000 . Consequently factor analysis was conducted since it was acceptable and useful. Table 1 shows that four components having Eigenvalues above 1 were extracted and they explained a total variance of $60.795 \%$.

To better understand the results a factor rotation was conducted as shown in Table 2.

The first component was named as Reliability. This factor with an eigenvalue of 2.16 explained $17.997 \%$ of variance. The second factor was named Firm Performance with an eigenvalue of 1.827 and it explained $15.222 \%$ of variance. The third factor was named Assurance with an eigenvalue of 1.507 and it explained $12.558 \%$ of variance. The last component was named Reputation with an eigenvalue of 1.151 and it explained $9.558 \%$ of variance.

\subsection{Descriptive Statistics: Importance of Audit Quality}

\begin{tabular}{lccc}
\hline \multicolumn{1}{c}{ Reliability } & Cronbach's Alpha & Mean & Std Deviation \\
\hline \multicolumn{1}{c}{$\begin{array}{l}\text { High audit quality enables a firm to confidently } \\
\text { confront criticism of its audited report. }\end{array}$} & 0.697 & 4.1130 & 0.67423 \\
$\begin{array}{l}\text { Audit quality ensures a true and fair view of the } \\
\text { firm financial position and performance. }\end{array}$ & 3.9500 & 0.99874 \\
$\begin{array}{l}\text { High quality financial statements increase a } \\
\text { firm's performance. }\end{array}$ & 4.1444 & 0.81276 \\
\hline
\end{tabular}

The mean score of Reliability is 4.113 which is higher than 4 , it can be deduced that on average the respondents agree that audit quality leads to reliability of financial statements. The statement "High audit quality enables a firm to confidently confront criticism of its audited report" has a mean score of 3.950. This is congruent with the findings of De Angelo [11] and Duff [12]. The statement "Audit quality ensures a true and fair view of the firm financial position and 
Table 1. Total variance explained.

\begin{tabular}{ccccccccccc}
\hline \multirow{2}{*}{ Component } & \multicolumn{3}{c}{ Initial Eigenvalues } & \multicolumn{2}{c}{ Extraction Sums of Squared Loadings } & \multicolumn{3}{c}{ Rotation Sums of Squared Loadings } \\
\cline { 2 - 10 } & Total & \% of Variance & Cumulative \% & Total & \% of Variance & Cumulative \% & Total & \% of Variance & Cumulative \% \\
\hline 1 & 2.160 & 19.638 & 19.638 & 2.160 & 19.638 & 19.638 & 1.931 & 17.552 & 17.552 \\
2 & 1.830 & 16.634 & 36.271 & 1.830 & 16.634 & 36.271 & 1.852 & 16.838 & 34.390 \\
3 & 1.512 & 13.746 & 50.017 & 1.512 & 13.746 & 50.017 & 1.553 & 14.121 & 48.511 \\
4 & 1.186 & 10.778 & 60.795 & 1.186 & 10.778 & 60.795 & 1.351 & 12.284 & 60.795 \\
\hline
\end{tabular}

Table 2. Rotated component matrix.

\begin{tabular}{|c|c|c|c|c|}
\hline & \multicolumn{4}{|c|}{ Component } \\
\hline & Reliability & Firm Performance & Assurance & Reputation \\
\hline $\begin{array}{l}\text { High audit quality enables a firm to confidently confront criticism } \\
\text { of its audited report. }\end{array}$ & 0.806 & & & \\
\hline $\begin{array}{l}\text { Audit quality ensures a true and fair view of the firm financial } \\
\text { position and performance. }\end{array}$ & 0.804 & & & \\
\hline High quality financial statements increase a firm's performance. & 0.738 & & & \\
\hline $\begin{array}{l}\text { Audit quality is an important contributor to successful } \\
\text { performance. }\end{array}$ & & 0.832 & & \\
\hline $\begin{array}{l}\text { High quality audit ensures due diligence in a firm's } \\
\text { policy-making and decision-making. }\end{array}$ & & 0.818 & & \\
\hline Audit quality helps to attract foreign direct investment. & & 0.655 & & \\
\hline Audit quality promotes good governance. & & & 0.774 & \\
\hline Audit quality helps to attract domestic investment. & & & 0.740 & \\
\hline $\begin{array}{l}\text { Audit quality is essential for effective risk management and } \\
\text { control. }\end{array}$ & & & 0.609 & \\
\hline $\begin{array}{l}\text { High quality audit enhances the image and reputation of both } \\
\text { auditor and auditee. }\end{array}$ & & & & 0.767 \\
\hline $\begin{array}{l}\text { High quality audit is essential for ensuring stakeholders' trust and } \\
\text { confidence in the audit firm. }\end{array}$ & & & & 0.750 \\
\hline
\end{tabular}

performance", has a mean score of 4.144. This confirms the findings of Francis [27] and De Fond \& Zhang [6]. It is observed that the findings of Aronmwan [21] and Susanty \& Gunawan [20] appear to be confirmed through the statements "High quality financial statements increase a firm's performance". This statement features a mean score of 4.244 .

\begin{tabular}{lccc}
\hline & Cronbach's Alpha & Mean & Std Deviation \\
\hline \multicolumn{1}{c}{ Firm Performance } & 0.627 & 4.0556 & 0.68458 \\
$\begin{array}{l}\text { Audit quality is an important contributor to successful } \\
\text { performance. }\end{array}$ & 4.0056 & 0.86842 \\
$\begin{array}{l}\text { High quality audit ensures due diligence in a firm's } \\
\text { policy-making and decision-making. }\end{array}$ & 4.3056 & 0.64381 \\
$\begin{array}{l}\text { Audit quality helps to attract foreign direct invest- } \\
\text { ment. }\end{array}$ & 3.8556 & 1.13414 \\
\hline
\end{tabular}


The mean score of Firm Performance was 4.055 which is higher than 4 . It can be deduced that on average respondents agree that audit quality ensures greater responsiveness of financial statements. The statement "Audit quality is an important contributor to successful performance" has a mean score of 4.005. This is tune with the findings of Geiger and Raghunandan [14] as well as Geiger and Rama [13]. The statement "High quality audit ensures due diligence in a firm's policy-making and decision-making", has a mean score of 4.305. This is in agreement with the IAASB [4] guidelines. The statement "Audit quality helps to attract foreign direct investment" has a mean score of 3.855. This is in line with the findings of Lennox [30]. The Cronbach's alpha for component Assurance and Reputation were 0.508 and 0.395 respectively. Since the Cronbach's alpha for both component was below 0.6 , their composite scores were not calculated.

\subsection{Exploratory Factor Analysis: Factors Affecting Audit Quality}

With the use of the Varimax method, a factor analysis was conducted to check whether different factors rearranged under the similar constructs. In order to assess the strength of the different factors, the Kaiser-Meyer-Olkin (KMO) Measure of Sampling Adequacy and the Barlett's test were carried out before the analysis. KMO was 0.514 which was higher than the required minimum of 0.50 and the significance value for the Barlett's test was 0.000 . Consequently factor analysis was conducted since it was acceptable and useful. Table 3 shows that five components having Eigenvalues above 1 were extracted and they explained a total variance of $65.363 \%$.

To better understand the results a factor rotation was conducted as shown in Table 4.

The first component was named as Expertise and Independence. This factor with an eigenvalue of 2.09 explained $16.823 \%$ of variance. The second factor was named Tenure and Restatements with an eigenvalue of 1.768 and it explained $14.736 \%$ of variance. The third factor was named Image with an eigenvalue of 1.412 and it explained $11.769 \%$ of variance. The fourth component was named Size with an eigenvalue of 1.395 and it explained $11.629 \%$ of variance. The last component was named 'Non-Audit Services and Rotation' with an eigenvalue of 1.249 and it explained $10.407 \%$ of variance.

\subsection{Descriptive Statistics: Factors Affecting Audit Quality}

The mean score of 'Expertise and Independence' (Table 5) was 4.17 which is higher than 4 . It may be inferred that on average respondents agree that expertise and independence of audit firm enhances audit quality. This is consistent with Meyer [31] and Reichelt and Wang [24] who found that audit firms having relevant industry expertise produce high quality of auditing.

The mean score of tenure and restatements (Table 6) is 4.0722 which implies that on average respondents agree that long auditor tenure enhances audit quality and financial restatements negatively impact audit quality. 
Table 3. Total variance explained.

\begin{tabular}{ccccccccccc}
\hline \multirow{2}{*}{ Component } & \multicolumn{3}{c}{ Initial Eigenvalues } & \multicolumn{3}{c}{ Extraction Sums of Squared Loadings } & \multicolumn{3}{c}{ Rotation Sums of Squared Loadings } \\
\cline { 2 - 10 } & Total & \% of Variance & Cumulative \% & Total & \% of Variance & Cumulative \% & Total & \% of Variance & Cumulative \% \\
\hline 1 & 2.019 & 16.823 & 16.823 & 2.019 & 16.823 & 16.823 & 1.939 & 16.158 & 16.158 \\
2 & 1.768 & 14.736 & 31.558 & 1.768 & 14.736 & 31.558 & 1.622 & 13.520 & 29.678 \\
3 & 1.412 & 11.769 & 43.327 & 1.412 & 11.769 & 43.327 & 1.538 & 12.818 & 42.497 \\
4 & 1.395 & 11.629 & 54.956 & 1.395 & 11.629 & 54.956 & 1.411 & 11.757 & 54.254 \\
5 & 1.249 & 10.407 & 65.363 & 1.249 & 10.407 & 65.363 & 1.333 & 11.109 & 65.363 \\
\hline
\end{tabular}

Table 4. Rotated component matrix.

\begin{tabular}{|c|c|c|c|c|c|}
\hline & \multicolumn{5}{|c|}{ Component } \\
\hline & $\begin{array}{l}\text { Expertise and } \\
\text { Independence }\end{array}$ & $\begin{array}{l}\text { Tenure and } \\
\text { Restatements }\end{array}$ & Image & Size & $\begin{array}{c}\text { Non-audit } \\
\text { services and rotation }\end{array}$ \\
\hline $\begin{array}{l}\text { Higher level of an audit firm's relevant industry expertise } \\
\text { increases audit quality. }\end{array}$ & 0.851 & & & & \\
\hline $\begin{array}{l}\text { Audit firm's expertise is better able to deliver audit quality } \\
\text { of high technical competence. }\end{array}$ & 0.837 & & & & \\
\hline High level of independence leads to high audit quality. & 0.697 & & & & \\
\hline Long auditor tenure leads to high audit quality. & & 0.883 & & & \\
\hline $\begin{array}{l}\text { Financial restatements of faulty statements negatively } \\
\text { impact audit quality. }\end{array}$ & & 0.866 & & & \\
\hline $\begin{array}{l}\text { An audit firm's concern about its image and reputation } \\
\text { drives higher audit quality }\end{array}$ & & & 0.853 & & \\
\hline $\begin{array}{l}\text { Concern about sustaining auditee's image or reputation } \\
\text { stimulates higher audit quality delivery by the audit firm. }\end{array}$ & & & 0.847 & & \\
\hline $\begin{array}{l}\text { The bigger an audit firm, the higher the level of its audit } \\
\text { quality. }\end{array}$ & & & & 0.840 & \\
\hline $\begin{array}{l}\text { A client's corporate image is enhanced by the reputation of } \\
\text { the bigger audit firm. }\end{array}$ & & & & 0.757 & \\
\hline Non-audit services lead to higher audit quality. & & & & & 0.822 \\
\hline Audit rotation improves audit quality. & & & & & 0.776 \\
\hline
\end{tabular}

The mean score of Brand Image (Table 7) is 3.319. It may be inferred that on average respondents are neutral regarding the effect of the brand image of an audit firm on audit quality.

The Cronbach's alpha for component 'Size and Credit Worthiness' and 'Rotation of Audit and Non-Audit Services' were 0.523 and 0.472 respectively. Since the Cronbach's alpha for both component was below 0.6 , their composite scores were not calculated. 
Table 5. Descriptive statistics for Expertise and Independence.

\begin{tabular}{lccc}
\hline & Cronbach's Alpha & Mean & Std Deviation \\
\hline \multicolumn{1}{c}{ Expertise and Independence } & 0.717 & 4.1741 & 0.69979 \\
$\begin{array}{l}\text { Higher level of an audit firm's relevant industry } \\
\text { expertise increases audit quality. }\end{array}$ & 4.0889 & 0.97619 \\
$\begin{array}{l}\text { Audit firm's expertise is better able to deliver } \\
\text { audit quality of high technical competence. }\end{array}$ & 4.2222 & 0.83603 \\
$\begin{array}{l}\text { High level of independence leads to high audit } \\
\text { quality. }\end{array}$ & 4.2111 & 0.80494 \\
\hline
\end{tabular}

Table 6. Descriptive statistics for Tenure and Restatements.

\begin{tabular}{lccc}
\hline & Cronbach's Alpha & Mean & Std Deviation \\
\hline \multicolumn{1}{c}{ Tenure and Restatements } & 0.732 & 4.0722 & 0.74204 \\
$\begin{array}{l}\text { Long auditor tenure leads to high audit } \\
\text { quality. }\end{array}$ & & 4.0500 & 0.79997 \\
$\begin{array}{l}\text { Financial restatements of faulty statements } \\
\text { negatively impact audit quality. }\end{array}$ & 4.0944 & 0.86971 \\
\hline
\end{tabular}

Table 7. Descriptive statistics for Image.

\begin{tabular}{lccc}
\hline & Cronbach's Alpha & Mean & Std Deviation \\
\hline \multicolumn{1}{c}{ Image } & 0.666 & 3.3139 & 1.10108 \\
$\begin{array}{l}\text { An audit firm's concern about its image } \\
\text { and reputation drives higher audit quality }\end{array}$ & & 3.4500 & 1.32140 \\
$\begin{array}{l}\text { Concern about sustaining auditee's image } \\
\text { or reputation stimulates higher audit } \\
\text { quality delivery by the audit firm. }\end{array}$ & & 3.1778 & 1.21974 \\
\hline
\end{tabular}

\subsection{Influence of Gender and level of Experience on Perception of} Respondents with Regards to Importance of Audit Quality

\begin{tabular}{cccc}
\hline & Reliability & Firm Performance \\
\hline Gender & Independent Sample T-Test & Significance Value $^{\star}$ & Significance Value $^{\star}$ \\
Level of Experience & One-way-ANOVA T-Test & 0.330 & 0.015 \\
\hline
\end{tabular}

It can be observed from the above table that there is no significant difference among male and female concerning Reliability. In fact the mean score for male is 4.07 and that of female is 4.17. It implies that both male and female agree that audit quality enhances reliability of financial statements. This finding is congruent with those of Susanty \& Gunawan [20] and Duff [12].

However there is a significant difference in the views of male and female concerning financial performance. The mean score for male is 3.94 and that of female is 4.19. It may be inferred that female are more agreeable that audit quality 
enhances firm performance. There is no significant difference among respondents with different experience level concerning Reliability. On average the respondents agreed that audit quality enhances reliability of financial statements with a mean score of 4.11. In addition there is no significant difference among respondents with different experience level with regards to firm performance. On average the respondents agreed that audit quality can enhance firm performance with a mean score of 4.06 .

4.6. Influence of Gender and Level of Experience on Perception of
Respondents with Regards to factors Affecting Audit Quality

There is no significant difference among male and female concerning expertise and independence. Both agree that expertise and independence of an audit firm enhances the quality of its audit. In fact the mean score of male and female is 4.19 and 4.14 respectively. This is in line with the findings of Hammersley [2] and Reichelt and Wang [24].

However there is a significant difference in the views of male and female concerning Tenure and Restatements. The mean score of male and female is 3.96 and 4.20 respectively. Female are more than agreeable than male that Long auditor tenure leads to high audit quality and that Financial restatements of faulty statements negatively impact audit quality. With regards to Image, there is no significant difference among male and female. Both male and female agree are neutral regarding the impact of image concern for both the audit firm and auditee on audit quality delivery by audit firm.

There is no significant difference among respondents with different experience level concerning Expertise and Independence. With a mean score of 4.17, respondents on average agreed that expertise and independence of an audit firm enhances the quality of its audit. In addition there is no significant difference among respondents with different experience level concerning Tenure and Restatements. With a mean score of 4.07 , respondents on average agreed that long auditor tenure leads to high audit quality and that financial restatements of faulty statements negatively impact audit quality.

Furthermore there is no significant difference among respondents with different experience level Image. With a mean score of 3.31, respondents on average are neutral regarding the impact of image concern for both the audit firm and auditee on audit quality delivery by audit firm. 


\section{Conclusion and Recommendations}

Majority of respondents have shown agreement with the statements based on the advocacies and findings of Sucher et al. [32], Turley and Willekens [1], Hay and Davies [33], Yassin et al. [10] bearing on the crucial importance of audit quality for its multiple beneficial contributions to successful corporate performance, and good governance in general. In addition the impacting factors on audit quality, by Turley and Willekens [1], regarding audit fees, firm size, tenure, reputation, financial statements-restatements, industry expertise, independence, non-audit services, and audit rotation, have been perceived as essential for achieving audit quality in Mauritius.

The study reveals that there is a significant difference in the views of male and female concerning financial performance. Female are more agreeable than male that audit quality enhances firm performance.

Furthermore the study reveals that there is a significant difference in the views of male and female concerning Tenure and Restatements. Female are more agreeable than male that Long auditor tenure leads to high audit quality and that financial restatements of faulty statements negatively impact audit quality. Things never being perfect in the contemporary context where loose morals are perceived as tarnishing country as well as corporate image and reputation, it looks primordial to work further towards higher levels of transparency and rigorous control of financial operations. It is recommended that rigorous due processes must be followed in terms of compliance with the standards or guidelines advocated for better exercising vigilance on both national and international financially-sensitive operations. In addition essential research and consultation mechanisms can be set up, operationalised by professionals of high integrity, with high-level expertise in monitoring and evaluating audit firms' conduct of auditees' assignments. Furthermore structures and supporting mechanisms must be put in place by authorities towards authentic management and leadership for steering corporate financial accounting and auditing standards, aligned on international norms, values and culture.

\section{Conflicts of Interest}

The authors declare no conflicts of interest regarding the publication of this paper.

\section{References}

[1] Turley, S. and Willekens, M. (2008) Auditing, Trust and Governance: Regulation in Europe.

[2] Hammersley, J.S. (2006) Pattern Identification and Industry-Specialist Auditors. The Accounting Review, 81, 309-336. https://doi.org/10.2308/accr.2006.81.2.309

[3] Choi, J.H., Kim, C., Kim, J.B. and Zang, Y. (2010) Audit Office Size, Audit Quality, and Audit Pricing. Auditing. A Journal of Practice \& Theory, 29, 73-97. https://doi.org/10.2308/aud.2010.29.1.73 
[4] International Auditing and Assurance Standards Board (IAASB) (2014) A Framework for Audit Quality.

[5] Francis, J.R. (2011) A Framework for Understanding and Researching Audit Quality. Auditing. A Journal of Practice \& Theory, 30, 125-152.

https://doi.org/10.2308/ajpt-50006

[6] DeFond, M. and Zhang, J. (2014) A Review of Archival Auditing Research. Journal of Accounting and Economics, 58, 275-326.

https://doi.org/10.1016/j.jacceco.2014.09.002

[7] Hussein, F.E. and Hanefah, M.M. (2013) Overview of Surrogates to Measure Audit Quality. International Journal of Business and Management, 8, 84.

https://doi.org/10.5539/ijbm.v8n17p84

[8] Hosseinniakani, S.M., Inacio, H. and Mota, R. (2014) A Review on Audit Quality Factors. International Journal of Academic Research in Accounting, Finance and Management Sciences, 4, 243-254.

[9] Dang, L. (2004) Assessing Actual Audit Quality. Doctoral Dissertation, Drexel University, Philadelphia.

[10] Jin, J.Y., Kanagaretnam, K. and Lobo, G.J. (2011) Ability of Accounting and Audit Quality Variables to Predict Bank Failure during the Financial Crisis. Journal of Banking \& Finance, 35, 2811-2819. https://doi.org/10.1016/j.jbankfin.2011.03.005

[11] DeAngelo, L.E. (1981) Auditor Size and Audit Quality. Journal of Accounting and Economics, 3, 183-199. https://doi.org/10.1016/0165-4101(81)90002-1

[12] Duff, A. (2004) Auditqual: Dimensions of Audit Quality. Institute of Chartered Accountants of Scotland, Edinburgh.

[13] Geiger, M.A. and Rama, D.V. (2006) Audit Firm Size and Going-Concern Reporting Accuracy. Accounting Horizons, 20, 1-17. https://doi.org/10.2308/acch.2006.20.1.1

[14] Geiger, M.A. and Raghunandan, K. (2002) Auditor Tenure and Audit Reporting Failures. Auditing: A Journal of Practice \& Theory, 21, 67-78. https://doi.org/10.2308/aud.2002.21.1.67

[15] O’Sullivan, N. and Diacon, S.R. (2002) The Impact of Ownership, Governance and Non-Audit Services on Audit Fees: Evidence from the Insurance Industry. International Journal of Auditing, 6, 93-107. https://doi.org/10.1111/j.1099-1123.2002.tb00007.x

[16] Yasin, F.M. and Nelson, S.P. (2012) Audit Committee and Internal Audit: Implications on Audit Quality. International Journal of Economics, Management and Accounting, 20, 187-218.

[17] Yuniarti, R. (2011) Audit Firm Size, Audit Fee and Audit Quality. Journal of Global Management, 2, 84-97.

[18] Kilgore, A. (2007) Corporate Governance Professional Regulation and Audit Quality. Malaysian Accounting Review, 6, 65-83.

[19] Crabtree, A.D. (2003) An Empirical Investigation of the Effects of Earnings Predictability and Auditor-Client Relationships on the Bond Credit Market. Doctoral Dissertation, Virginia Tech.

[20] Susanty, M. and Gunawan, J. (2015) Audit Quality to Manage Sustainable Auditor Reputation. Issues in Business Management and Economics, 3, 100-108.

[21] Aronmwan, E.J., Ashafoke, T.O. and Mgbame, C.O. (2013) Audit Firm Reputation and Audit Quality. European Journal of Business and Management, 5, 66-75. 
[22] Liu, L.L., Raghunandan, K. and Rama, D. (2009) Financial Restatements and Shareholder Ratifications of the Auditor. Auditing. A Journal of Practice \& Theory, 28, 225-240. https://doi.org/10.2308/aud.2009.28.1.225

[23] Romanus, R.N., Maher, J.J. and Fleming, D.M. (2008) Auditor Industry Specialization, Auditor Changes, and Accounting Restatements. Accounting Horizons, 22, 389-413. https://doi.org/10.2308/acch.2008.22.4.389

[24] Reichelt, K.J. and Wang, D. (2010) National and Office-Specific Measures of Auditor Industry Expertise and Effects on Audit Quality. Journal of Accounting Research, 48, 647-686. https://doi.org/10.1111/j.1475-679X.2009.00363.x

[25] Roberts, M.L. (2010) Independence, Impartiality, and Advocacy in Client Conflicts. Research in Accounting Regulation, 22, 29-39.

https://doi.org/10.1016/j.racreg.2009.11.001

[26] Alleyne, A. and Devonish, D. (2006) Perceptions of Auditor Independence in Barbados. Managerial Auditing Journal, 21, 621-635. https://doi.org/10.1108/02686900610674898

[27] Francis, J.R. (2004) What Do We Know about Audit Quality? The British Accounting Review, 36, 345-368. https://doi.org/10.1016/j.bar.2004.09.003

[28] Thornton, J.M. and Shaub, M.K. (2013) Tax Services, Consequence Severity, and Jurors' Assessment of Auditor Liability. Managerial Auditing Journal, 29, 50-75. https://doi.org/10.1108/MAJ-03-2013-0834

[29] Dopuch, N., King, R.R. and Schwartz, R. (2001) An Experimental Investigation of Retention and Rotation Requirements. Journal of Accounting Research, 39, 93-117. https://doi.org/10.1111/1475-679X.00005

[30] Lennox, C.S. (1999) Audit Quality and Auditor Size: An Evaluation of Reputation and Deep Pockets Hypotheses. Journal of Business Finance \& Accounting, 26, 779-805. https://doi.org/10.1111/1468-5957.00275

[31] Meyer, K. (2009) Industry Specialization and Discretionary Accruals for Big 4 and Non-Big 4 Auditors. The Florida State University, Tallahassee.

[32] Sucher, M. and Zarova, M. (1999) The Images of the Big Six Audit Firms in the Czech Republic. European Accounting Review, 8, 499-521.

https://doi.org/10.1080/096381899335916

[33] Hay, D. and Davis, D. (2004) The Voluntary Choice of an Auditor of Any Level of Quality. Auditing: A Journal of Practice \& Theory, 23, 37-53.

https://doi.org/10.2308/aud.2004.23.2.37 